\title{
MIMO Control Loop using Multipletanks System to Control the Level using LabView
}

\author{
B. Kalaiselvi, D. Sridharraja, T. Vijayan
}

\begin{abstract}
The modernisation of the current arrangement of information securing framework in procedure control is moved up to the ongoing innovations for running the procedure station. This paper gives the perspectives on the current 3 tank frameworks set up is utilized for controlling the degrees of 2 associating frameworks. Fluid level control has a huge application area in industry move over; the three tank framework is one of the most broadly utilized examinations in lab and research organizations. The estimation of modern procedure level parameter is one of the extraordinary significances in procedure control. The degree of fluids may influence both the weight and pace of stream all through the tank. Thus, the quality might be influenced. Programmed control applications will require control signals for activity of incitation. Level transmitter is utilized to gauge level of the tank. In this framework the level in the process tank is detected utilizing a level transmitter and the comparing current yield being estimated and constrained by utilizing information obtaining framework. [1],[3],[5]
\end{abstract}

Keywords : Closed loop, Cascade control, LabView, Virtual Instrumentation

\section{INTRODUCTION}

Mechanical control frameworks are utilized in gear or hardware for modern productionor control.Two kinds of control frameworks arecommon, open circle control frameworks and shut circle control systems.There are two normal classes of control framework, open circle control frameworks and shut circle control frameworks. In open circle control system yield is made subject to data sources. In shut circle control structures current yield is considered and corrections are made reliant on analysis. [2 ],[ 4],[6]

A shut circle framework is additionally called a criticism control framework. Strategy control is the exhibit of controlling a last controller part to change the controlled variable to keep up the methodology variable at a perfect set point .The controlled variable is an extent of advantage being supported into the technique. Last control component is the gadget that changes the estimation of the controlled variable. The controller yield is the sign from the controller to the last control component. The procedure variable is the proportion of the procedure yield that adjustments because of changes in the controlled variable. The set point is the incentive at which we wish to keep up the procedure variable

Revised Manuscript Received on August 22, 2019.

B.Kalaiselvi, Department of EIE, Bharath Institute of Higher education and research, Tamilnadu, India. Email: kalaiselvi.eie@bharathuniv.ac.in

Sridhar Raja D Department of EIE, Bharath Institute of Higher Education and Research, Tamilnadu, India. Email: sridharraja.eie@bharathuniv.ac.in

T.Vijayan, Department of EIE,Bharath Institute of Higher education and research, Tamilnadu, India. Email: vijayan.eie@bharathuniv.ac.in

\section{PROPOSED EXPERIMENTAL SYSTEM}

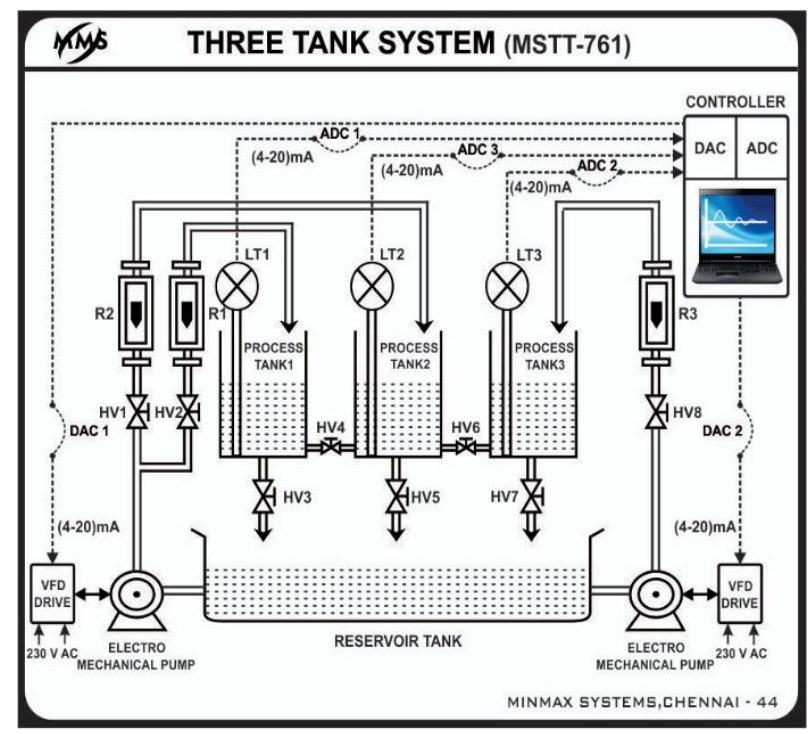

Figure.1Proposed system in real time

This the experimental system used the Closed loop block diagram is shown in the Labview screen developed according to the proposed system. In cascade there are two loops one the master whose set point does not changes so often whereas the output of the master loop is going to be the set point of the slave loop hence the designing of slave loop controller plays a vital role in bringing the two tanks to the required set point.

DAQ: The data acquisition system which acquires all the data from the real time three tank process station which is used to interface all the analog inputs from the real time process and processed by the controller designed for the stability of the proposed system and the controller output is given to the final control element through DAC and the current to pressure converter. [7],[9], ,[11]

Cascade Control: The cascade analyser block diagram is designed as shown in the figure; the cascade control is basically have primary and secondary loops whose controller are master and slave controller. Master's set point does not vary rapidly where as the slave set point varies rapidly. In spite of variations in the set point the controller design is a tedious process. [8],[10],[12]

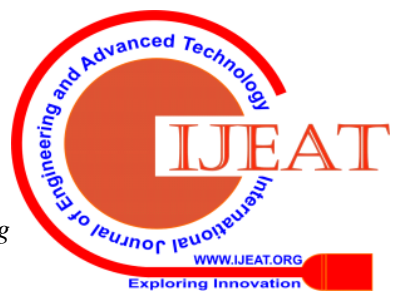




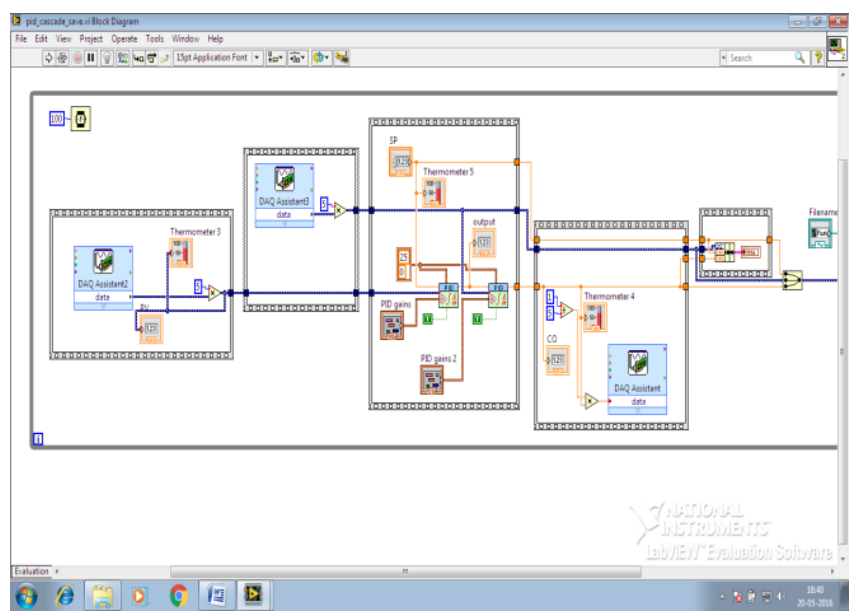

Figure2. Schematic of Cascade control system

After building the block diagram in LabView the continuously run operation is chosen in the file menu. The Cascade connection can be viewed from the Labview window panel as shown in fig 3. [13], [15], [17]

The final Control element is the pneumatic control valve. This control valve is controlled by the manipulated variable given from the controller via current to pressure converter. [14],[ 16], [18]

\section{RESULTS AND DISCUSSIONS}

The process data is tabulated using Excel format and the process running window also shows the level of the two tanks virtually also as shown in the figure.

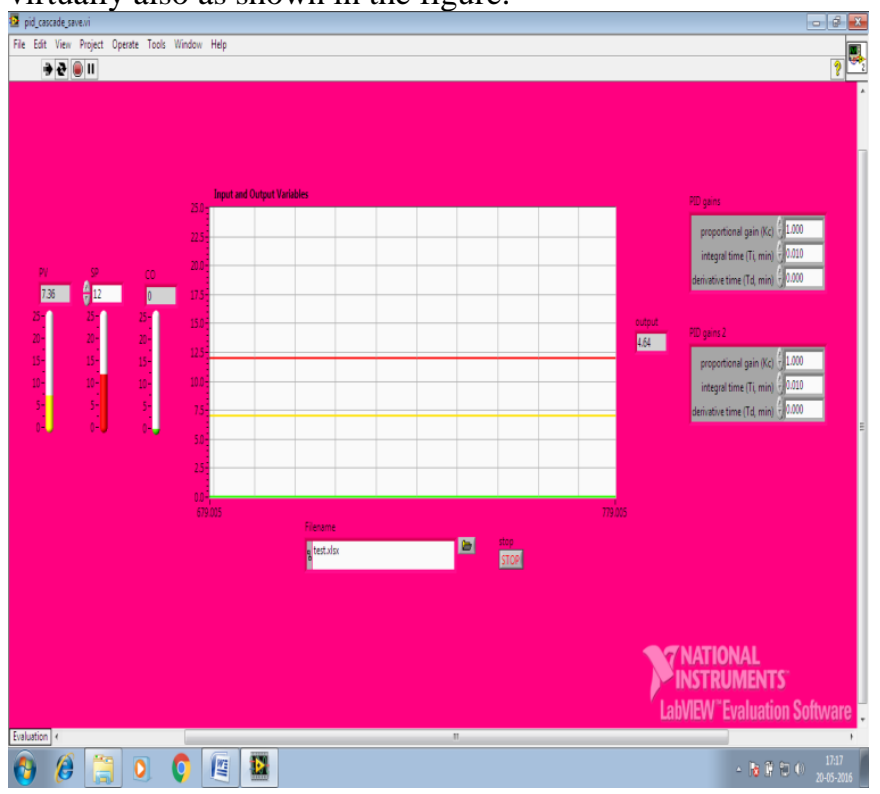

Figure.3Window in virtual set up using LabView

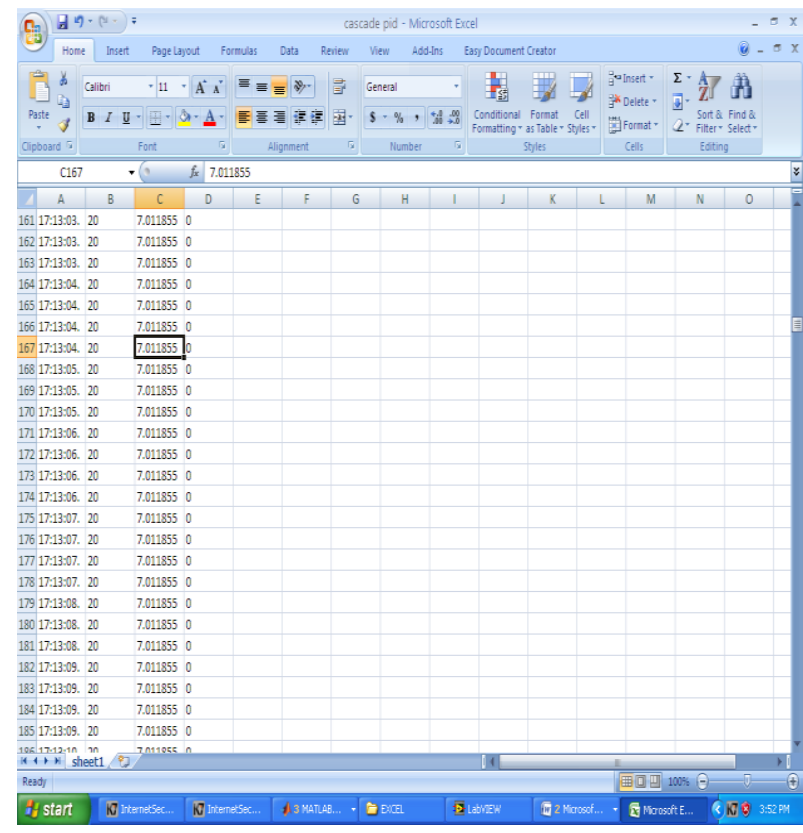

Figure 4 Excel Data format for the cascade Control System

\section{DISCUSSIONS}

Hereby we can conclude that the existing systems with convention methodologies and programming languages can be replaced with trending software's and technologies by just comparing and applying the algorithms of related process control. [19],[20],[21]

\section{REFERENCES}

[1] Sharma, R.K., Irusapparajan, G. \& Periyaazhagar, D. 2019 , "Three-phase symmetric cascading Z-source seven levels multilevel inverter excited by multi carrier sinusoidal pulse width modulation scheme", International Journal of Innovative Technology and Exploring Engineering, vol. 8, no. 10, pp. 4269-4274.

[2] Velavan, R., Bharanidharan, S. \& Sheeba, B. 2019, "EMF pollution Causes, effects and protection", International Journal of Innovative Technology and Exploring Engineering, vol. 8, no. 9 Special Issue 3, pp. 1166-1168.

[3] Saravana, S., Balaji, S., Arulselvi, S. \& John Paul Praveen, A. 2019 "Reliable power quality monitoring and protection system", International Journal of Innovative Technology and Exploring Engineering, vol. 8, no. 9 Special Issue 3, pp. 644-645

[4] Tamil Selvan, S. \& Sundararajan, M. 2019, "Performance Parameters of 3 Value 8t Cntfet Based Sram Cell Design Using H-Spice", International Journal of Recent Technology and Engineering, vol. 8, no. 2 Special issue 5, pp. 22-27.

[5] Jac Fredo, A.R., Abilash, R.S., Femi, R., Mythili, A. \& Kumar, C.S. 2019, "Classification of damages in composite images using Zernike moments and support vector machines", Composites Part B: Engineering, vol. 168, pp. 77-86.

[6] Kathiravan, P. \& Govindaraju, C. 2019, "Design and evaluation of ultra gain isolated DC-DC converter for photovoltaic system", International Journal of Engineering and Advanced Technology, vol. 8, no. 5, pp. 2646-2651.

[7] Kripa, N., Vasuki, R. \& Kishore Kanna, R. 2019, "Realtime neural interface controlled au-pair BIMA bot", International Journal of Recent Technology and Engineering, vol. 8, no. 1, pp. 992-994.

[8] Mohanraj, Meenaa Kumari, M., Philomina, S. \& Jasmin, M. 2019 , "In-situ humidity measurement of hydrogen fuel cell car using MEMS sensor", International Journal of Recent Technology and Engineering, vol. 8, no. 1, pp. 41-43.

[9] Velmurugan, T. \& Prakash, S. 2019, "Artificial intelligent based distribution automation of swift fault detection isolation and power restoration for HT network", International Journal of Innovative Technology and Exploring Engineering, vol. 8, no. 6, pp. 1-6.

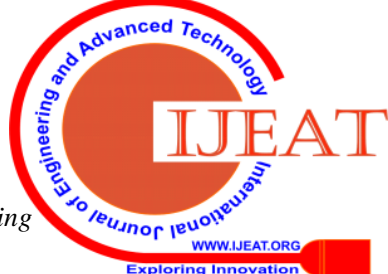


[10] Dwarakesh, K. \& Prem Kumar, G. 2019, "Five-level inverter based sequential boost system using fuzzy logic controller", International Journal of Innovative Technology and Exploring Engineering, vol. 8, no. 6, pp. 12-19.

[11] Anne Gifta, A. \& Hemavathi, G. 2019, "Analysis of grid tied solar PV system using ANFIS Algorithm", International Journal of Innovative Technology and Exploring Engineering, vol. 8, no. 6, pp. 312-316.

[12] Jayavel, R., Rangaswamy, T.R. \& Prakash, S. 2019, "Efficient grid management system with renewable and conventional power sources", International Journal of Innovative Technology and Exploring Engineering, vol. 8, no. 6, pp. 287-289.

[13] Hemavathi, G. \& Maheshwaran, S. 2019, "Proportional resonant controlled high gain step-up converter system with improved response", International Journal of Innovative Technology and Exploring Engineering, vol. 8, no. 6, pp. 317-323.

[14] Periyaazhagar, D. \& Irusapparajan, G. 2019, "Design and completion of asymmetric single phase 27 level cascaded mli for various pwm scheme", International Journal of Innovative Technology and Exploring Engineering, vol. 8, no. 6, pp. 792-797.

[15] Mahalakshmi, V. \& Vijayaragavan, S.P. 2019, "PV based power electronic converters for high voltage DC applications", International Journal of Recent Technology and Engineering, vol. 7, no. 6, pp. 670-674.

[16] Irusapparajan, G., Periyaazhagar, D., Prabaharan, N. \& Rini Ann Jerin, A. 2019, "Experimental verification of trinary DC source cascaded h-bridge multilevel inverter using unipolar pulse width modulation", Automatika, vol. 60, no. 1, pp. 19-27.

[17] Sangeetha, G., Sherine, S., Arputharaju, K. \& Prakash, S. 2019, "On Line Monitoring of Higher Rated Alternator using Automated Generator Capability Curve Administer", Proceedings of the IEEE International Conference on \&amp;quot;Recent Trends in Electrical, Control and Communication\&amp;quot;, RTECC 2018, pp. 176.

[18] Bycil, V.J. \& Wiselin, M.C.J. 2019, "Modeling and analysis of vibration energy harvesting system using piezo stack", International Journal of Mechanical and Production Engineering Research and Development, vol. 9, no. Special Issue 1, pp. 523-533.

[19] Sripada, A., Warrier, A., Kapoor, A., Gaur, H. \& Hemalatha, B. 2018 , "Dynamic lateral balance of humanoid robots on unstable surfaces", International Conference on Electrical, Electronics, Communication Computer Technologies and Optimization Techniques, ICEECCOT 2017, pp. 539.

[20] Srinivasan, S., Thirumalaivasan, K. \& Sivakumaran, T.S. 2018, "Performance evaluation of double-output luo converters", Journal of Advanced Research in Dynamical and Control Systems, vol. 10, no. 10 Special Issue, pp. 870-878.

[21] Karthikayen, A. \& Selvakumar Raja, S. 2018, "A skellam distribution inspired trust factor-based selfish node detection technique in MANETs", Journal of Advanced Research in Dynamical and Control Systems, vol. 10, no. 13, pp. 940-949.

\section{AUTHORS PROFILE}

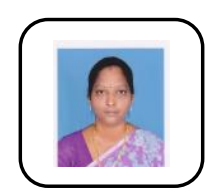

B.Kalaiselvi, Assistant Professor, Department of EIE,Bharath Institute of Higher education and research, Tamilnadu, India

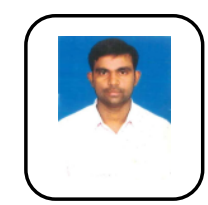

Sridhar raja D, Assistant Professor, Department of EIE,Bharath Institute of Higher education and research, Tamilnadu, India.

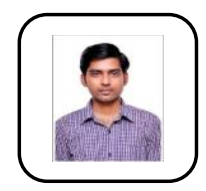

T.Vijayan, Assistant Professor, Department of EIE,Bharath Institute of Higher education and research, Tamilnadu, India. 